\title{
REMOTE NEUROREHABILITATION PORTAL FUNCTIONALITY
}

\author{
T.N. Ivanilova ${ }^{a}$ I.V. Vasilenko , V.A. Semenova, I.A. Buslova, A.A. Ilminskayab ${ }^{b}$ S.A. Subocheva ${ }^{b}$ \\ a Reshetnev Siberian State University of Science and Technology (Reshetnev University),Krasnoyarsk, 660037, Russian Federation \\ b Krasnoyarsk State Medical University named after Prof. V.F.Voino-Yasenetsky, Krasnoyarsk, 660022, Russian Federation \\ Corresponding author: Vasilenko_irina@myrambler.ru \\ Article info \\ Received 08.06.19, accepted 09.07.19 \\ Article in English \\ For citation: Ivanilova T.N., Vasilenko I.V., Semenov V.A., Buslov I.A., Ilminskaya A.A., Subocheva S.A. Remote neurorehabilitation portal \\ functionality. Scientific and Technical Journal of Information Technologies, Mechanics and Optics, 2019, vol. 19, no. 5, pp. 925-930 (in English). \\ doi: 10.17586/2226-1494-2019-19-5-925-930
}

\section{Abstract}

The paper presents a portal developed for remote rehabilitation of patients with various neurological pathologies. The distinctive features of the developed system as compared with the existing ones are: the possibility of patient communication with the attending doctor, timely updating of the patient's individual trajectory of rehabilitation, control of the rehabilitation results through online monitoring of the patient's health condition by the video recording function integrated into the system, rehabilitation opportunities for patients in outlying areas of the Krasnoyarsk Territory. The software implementation of rehabilitation is based on proprietary medical methodologies developed at the Department of Nervous Diseases with a course of medical rehabilitation for postgraduate education at Krasnoyarsk State Medical University named after V.F. Voyno-Yasenetsky (Scientific Supervisor is MD, Professor S.V. Prokopenko). The paper pays special attention to the functionality of the remote rehabilitation system for the users with the roles: "Doctor", "Patient" and "Administrator". Screenshots of the portal are presented. The system is a classic Web application built on free software. The presented work can be useful to neurorehabilitation specialists of the Krasnoyarsk Territory and to specialists throughout Russia. The proposed information system can be also used for patients' rehabilitation exercise training of doctors and nurses.

Keywords

remote rehabilitation, neurorehabilitation, information system, information system functions, database, home rehabilitation, information and communication technologies

\section{Acknowledgements}

The "NeuroDom" project of home remote neurorehabilitation was supported by a grant from the Krasnoyarsk Regional Fund for Support of Scientific and Technological Activities (code: 2018042003718), as part of the Scientific and Technological Research, Development, Innovation Programs and Projects Competition for providing the competitive advantages of the Krasnoyarsk Territory economy.

УДК 004.043, 004.9

doi: 10.17586/2226-1494-2019-19-5-925-930

\section{ФУНКЦИОНАЛЬНЫЕ ВОЗМОЖНОСТИ ПОРТАЛА ДИСТАНЦИОННОЙ НЕЙРОРЕАБИЛИТАЦИИ}

Т.Н. Иванилова $а$, И.В. Василенко, В.А. Семенова, И.А. Буслова, А.А. Ильминская ${ }^{\mathrm{b}}$, С.А. Субочева а Сибирский государственный университет науки и технологий им. академика М.Ф. Решетнева, Красноярск, 660037, Российская Федерация

b Красноярский государственный медицинский университет им. профессора В.Ф. Войно-Ясенецкого, Красноярск, 660022,

Российская Федерация

Адрес для переписки: Vasilenko_irina@myrambler.ru

Информация о статье

Поступила в редакцию 08.06.19, принята к печати 09.07.19

Язык статьи - английский

Ссылка для цитирования: Иванилова Т.Н., Василенко И.В., Семенов В.А., Буслов И.А., Ильминская А.А., Субочева С.А. Функциональные возможности портала дистанционной нейрореабилитации // Научно-технический вестник информационных технологий, механики и оптики. 2019. Т. 19. № 5. С. 925-930 (на англ. яз.). doi: 10.17586/2226-1494-2019-19-5-925-930

\section{Аннотация}

Разработан портал дистанционной реабилитации пациентов с различными неврологическими патологиями. Отличительными особенностями разработанной системы перед существующими является: возможность коммуникации пациента с лечащим врачом, своевременная корректировка индивидуальной траектории реабилитации пациента, контроль 
результатов реабилитации путем онлайн-мониторинга состояния здоровья пациента с помощью встроенной в систему функции записи видео, создание возможности реабилитации для пациентов в отдаленных точках Красноярского края. Программная реализация реабилитации базируется на авторских медицинских методиках, разработанных на кафедре нервных болезней с курсом медицинской реабилитации последипломного образования Красноярского государственного медицинского университета им. профессора В.Ф. Войно-Ясенецкого (научный руководитель д.м.н., профессор С.В. Прокопенко). Показаны функциональные возможности работы системы дистанционной реабилитации пользователей с ролями «Врач», «Пациент» и «Администратор». Представлены скриншоты портала. Система представляет собой классическое веб-приложение, построенное на свободном программном обеспечении. Представленная работа может быть полезна нейрореабилитологам Красноярского края и специалистам по всей России. Предложенную информационную систему можно использовать также для обучения врачей и медсестер различным упражнениям для реабилитации пациентов.

\section{Ключевые слова}

дистанционная реабилитация, нейрореабилитация, информационная система, функции информационной системы, база данных, домашняя реабилитация, информационно-коммуникационные технологии

\section{Благодарности}

Проект дистанционной домашней нейрореабилитации «НейроДом» поддержан грантом «Красноярского краевого фонда поддержки научной и научно-технической деятельности» (код: 2018042003718) в рамках проведения Конкурса научно-технических исследований, разработок, инновационных программ и проектов для обеспечения конкурентных преимуществ экономики Красноярского края.

\section{Introduction}

Every year, the introduction of information and communication technologies improves the efficiency and quality of work in the health sector. The developed systems are used in the field of laboratory service automation, advisory computational diagnostics and the choice of treatment tactics, monitoring of a patient's condition, scientific research, in the educational process and the other areas [1].

In order to achieve high-quality recovery from diseases or injuries of the nervous system functions, it is necessary to carry out rehabilitation measures prescribed by a doctor for a long time. These prescriptions often do not fit into the inpatient treatment.

Existing information systems for remote rehabilitation either lean towards the use of equipment, or do not have support in the Russian Federation, or do not cover the whole range of the functionality presented below.

The information system considered in the article belongs to a new field of research - telemedicine, and is the first software development of the proprietary medical methodology (S.V. Prokopenko et al., Russian Patent 2013). The system, implemented as a web portal, contains a set of remotely prescribed rehabilitation video exercises by a doctor, provides for feedback from patients, accumulating statistical information on patients, etc. This functionality will be presented in more detail below and has not been previously implemented in the other similar information systems [2].

The operation of any information system consists of such steps as data-in, processing input information and presenting it in a convenient form, data-out for presenting to the consumer, providing feedback. So we list the following project tasks:

1. Combine, into a single methodology, proprietary and well-known rehabilitation methods aimed at motor function recovery, intellectual activity, fine motor skills, balance and walking for patients with neurological and orthopedic pathology.

2. Develop an adaptive design of the NeuroDom Internet portal [3].

3. Design and develop a database that will provide secure storage of personal data. All stages of patient rehabilitation will be stored in this database, also as medical scales; the handbook of the International Classification of Diseases will be connected to it [4].

4. Create a video-series of exercises describing the anatomy of the joints and muscles, the operating technique, the functional component of each exercise.

5. Develop algorithms that implement the technology of information collecting, storing, processing and presenting.

6. Code and program the portal to place the site files on the servers.

7. Fill the portal with information: text, graphics, video, photos, etc.

8. Perform testing of the "NeuroDom" portal on real data.

The work performers of the project are Reshetnev Siberian State University of Science and Technology (SibSU named after M.F. Reshetnev) and Krasnoyarsk State Medical University named after V.F. Voyno-Yasenetsky (hereafter - KrasSMU).

\section{Description of the patients' rehabilitation process using the "NeuroDom" information system}

After the patient has undergone the initial period of rehabilitation in the hospital, the doctor can assess his health condition using medical functional scales [5, 6], with the application of the information system functionality. Next, the doctor prescribes the rehabilitation complex of exercises on the "NeuroDom" portal. Exercises are presented in the form of video clips and are based on the copyrighted medical methodologies, which are developed 
at the Department of Nervous Diseases with a medical rehabilitation course of postgraduate education at KrasSMU named after V.F. Voyno-Yasenetsky (Scientific Supervisor is MD, Prof. S.V. Prokopenko) [7].

Fig. 1 presents a diagram of use cases that describes the relations and dependencies between users (patient, doctor, technical support) involved in the rehabilitation process [8].

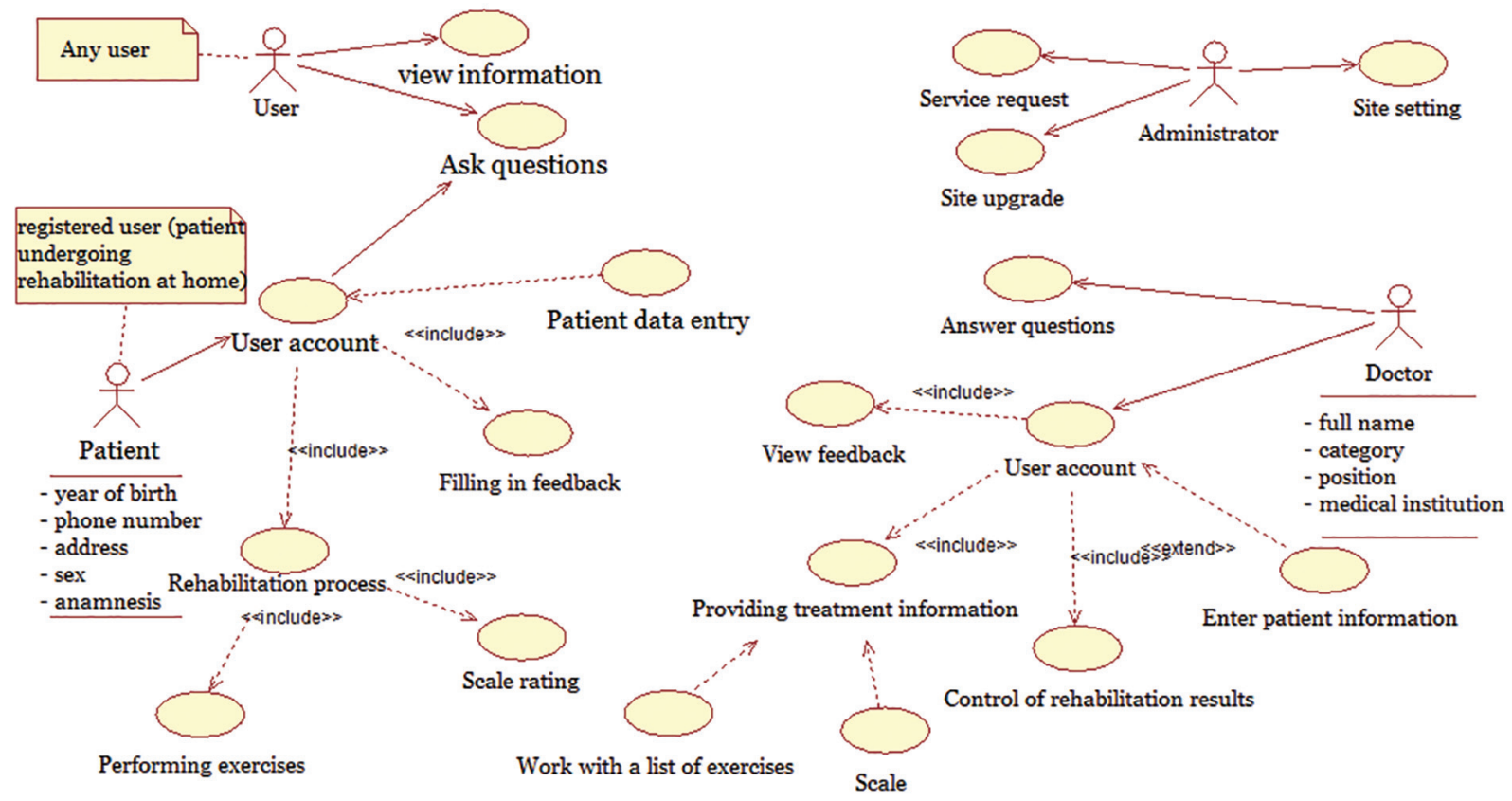

Fig. 1. General use case diagram

The database is implemented in such a way that it would be possible to ensure the security of personal data storage. Two servers are used for the system. One server is used for storing personal data within the network and the main server is aimed for storing data and using the system on the Internet.

The system activity is carried out using browsers such as Mozilla Firefox, Google Chrome, etc.

The system has a mechanism for registering and authenticating users, based on entering the correct combination of username and password. Thus, the separation of functionality according to access rights is achieved for:

1. Doctor;

2. Patient;

3. Administrator.

The user's functionality with the role of a "Doctor" allows accessing the exercise management interface: viewed, added new, modified, deleted, grouped exercises into categories (Fig. 2).

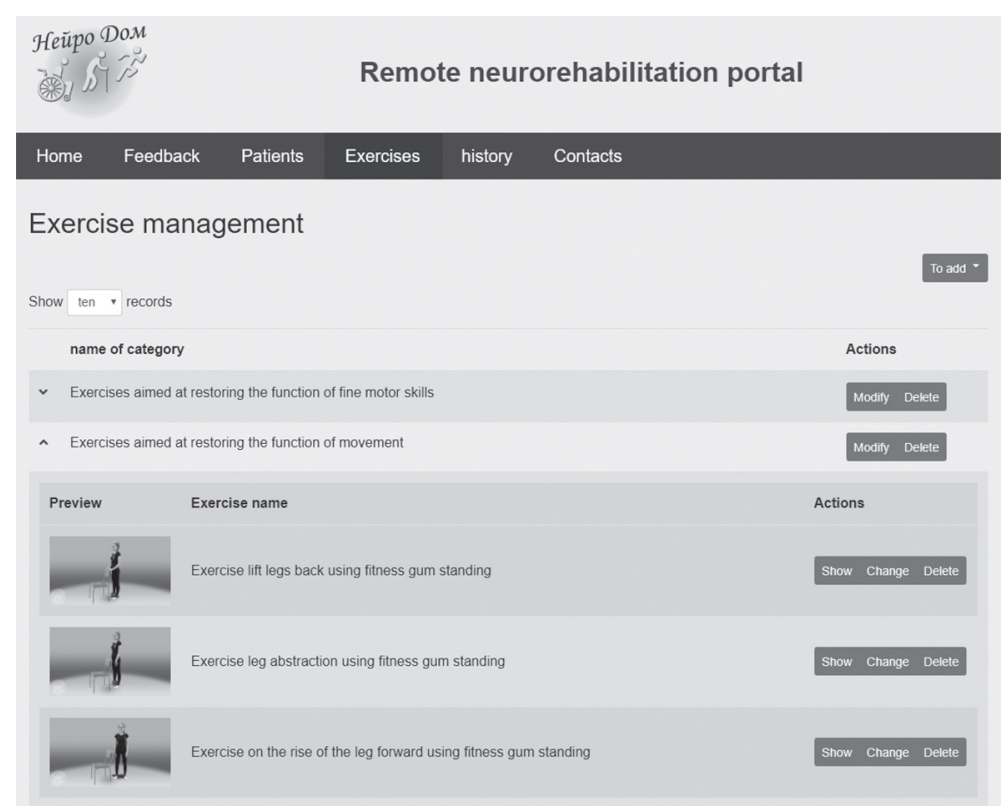

Fig. 2. The exercise list 
The doctor has an access to view a list of all patients. Each patient is attached to his own attending doctor, who has the right to change his personal data, unlike the other doctors.

The doctor indicates the number of days and the time for the complex of exercises, in the process of prescribing a course of exercises (Fig. 3). A graph is plotted based on the completed and unfulfilled exercises with relation to a predetermined period of time.

The menu item "Feedback" displays a list of conversations with patients and the number of unread messages. This functionality is designed for communication between a doctor and a patient with text messages and attachments, such as pictures and recorded videos. The function of video recording and sending is added in the presented system.

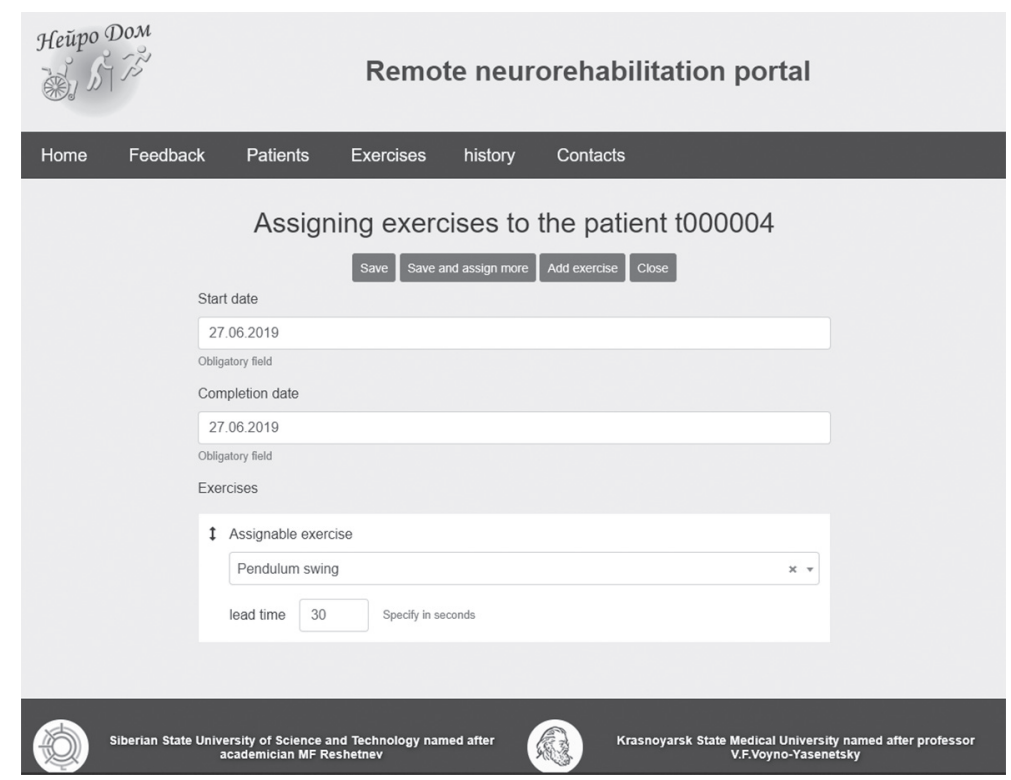

Fig. 3. Prescription of the exercise set

The menu item "History of actions" displays a list of all patients' actions that can be filtered by date, patient, action categories (Fig. 4).

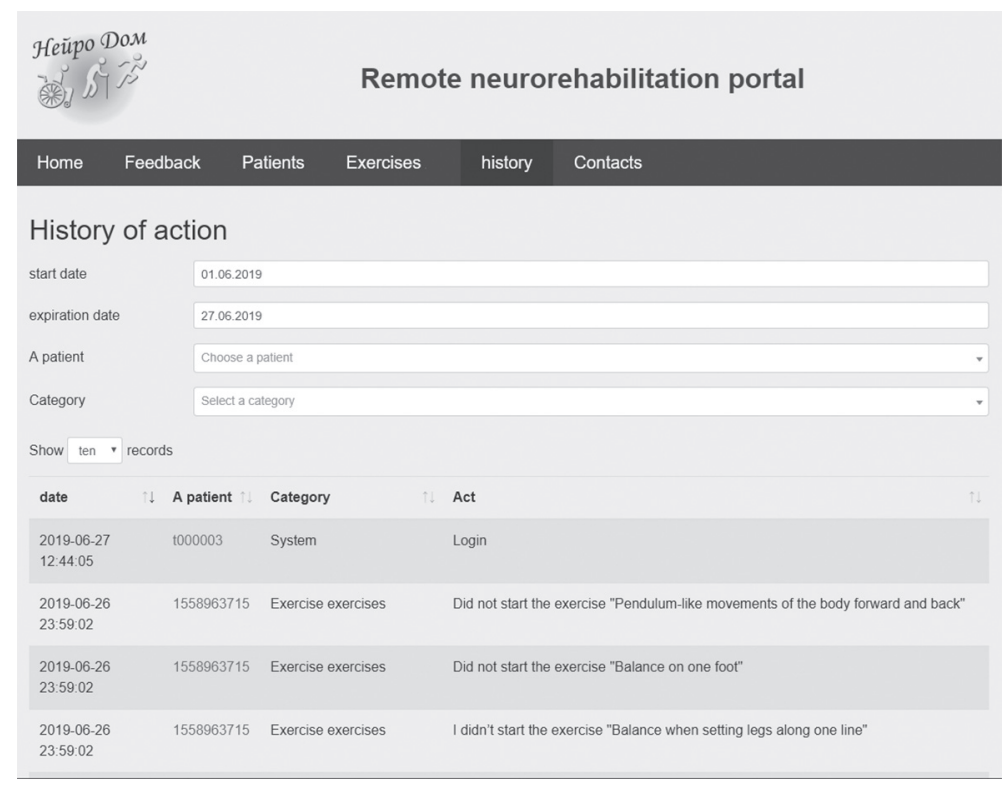

Fig. 4. History of actions

The user's functionality with the role of a "Patient" allows accessing to a personal account where the personal information can be edited, photos can be added, as well as the history and schedule of exercises is shown.

When the patient enters the menu item "Exercises", he sees the list of exercises for today with a description and a video instruction how to do it (Fig. 5). 


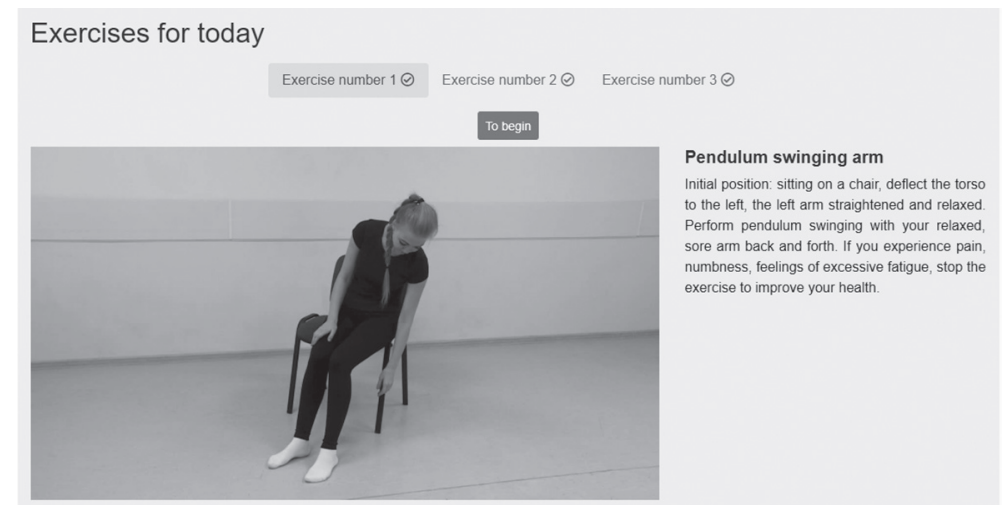

Fig. 5. Performing an exercise

Before starting the exercise, you should enter the blood pressure and pulse. After entering the data, the video will start, and the patient can perform the exercise. After finishing the exercise, the patient can click on the "Completed" button and the exercise will be reckoned as completed or "Could not be completed" and then a window will open in which you need to enter a comment about the problem with the exercise, which will be sent to the doctor.

The user's functionality with the role of an "Administrator" allows accessing to:

— the content management of the portal that gives the possibility to edit the pages of the site, register and edit users with the roles of a "Doctor" and a "Patient";

— management of security and access rights;

- management of scales and neurological status with the possibility to add new and edit existing scales.

The information system is designed in such a way that new scales can be connected to it without changing the source codes and database structure.

Automated data collection of users' actions is realized, and then can be processed and retrieve statistical data.

Linux CentOS 7 is used as a server operating system and PostgreSQL - as a database. The system is implemented in PHP7, using the Symfony 3 framework [9]. On the front-end of the application, the Twitter Bootstrap [10-12] framework is used in conjunction with the jQuery library [13, 14], using HTML5 and CSS3 [15, 16].

\section{Conclusion}

The authors presented the functions of the "NeuroDom" information system by describing the users' options with the roles: Doctor, Patient and Administrator.

The information system is designed to create continuous rehabilitation at home with the implementation of feedback from the doctor; also it gives the possibility to create and carry out online monitoring of the individual rehabilitation trajectory of patients living in outlying areas of the Krasnoyarsk Territory, which will reduce the level of disability.

The following tasks were implemented in the course of this work: the design of the portal was developed; the database was designed and developed; a video-series of exercises with the description of the joints and muscles anatomy was created, the technique of execution was designed; code and programming of the portal was finished; content was filled; site files are hosted on KrasSMU servers.

The information system is designed in such a way that new scales can be connected to it without changing the source codes and database structure.

Automated data collection of user actions has been implemented. This data can be processed to get statistics.

The portal has been implemented and is at the stage of testing and preparation for the adoption into the Prof. Clinic of Krasnoyarsk State Medical University named after V.F. Voyno-Yasenetsky.

\section{Литература}

1. Евсеев А.В., Мышенков К.С. Проектирование информационных систем: Учебное пособие. М.: Изд-во Комплекс МГУПП, 2006. 190 с.

2. Иванилова Т.Н., Прокопенко С.В., Попов А.А., Демидюк В.Д., Буслов И.А., Субочева С.А. Проектные решения портала дистанционной нейрореабилитации «Нейродом» // Врач и информационные технологии. 2019. № 1. С. 73-80.

3. Иванилова Т.Н., Василенко И.В., Семенов В.А. Дизайнпроект дистанционного портала домашней реабилитации // Современные тенденции развития педагогических технологий в медицинском образовании: сборник статей Всероссийской

\section{References}

1. Evseev A.V., Myshenkov K.S. Information systems design. Tutorial. Moskow, Publishing complex of MGUPP, 2006, 190 p. (in Russian)

2. Ivanilova T.N., Prokopenko S.V., Popov A.A., Demidyk V.D., Buslov I.A., Subocheva S.A. Project design portal teleservicing neurorehabilitation "Neyrodom". Physician and information technologies, 2019, no. 1, pp. 73-80. (in Russian)

3. Ivanilova T.N., Vasilenko I.V., Semenov V.A. Design project of remote portal of home rehabilitation. Modern trends in the development of pedagogical technologies in medical education: Proc. All-Russian Conf. with International Participation 
научно-практической конференции с международным участием, Красноярск, 7-8 февраля 2018 года. Красноярск: КрасГМУ им. проф. В.Ф. Войно-Ясенецкого, 2018. С. 326-332.

4. Попов А.А., Буслов И.А., Фрышкина В.Д. Проектирование базы данных портала домашней нейрореабилитации // Современные тенденции развития педагогических технологий в медицинском образовании: сборник статей Всероссийской научно-практической конференции с международным участием, Красноярск, 7-8 февраля 2018 года. Красноярск: КрасГМУ им. проф. В.Ф. Войно-Ясенецкого, 2018. С. 357-361.

5. Белова А.Н. Шкалы, тесты и опросники в неврологии и нейрохирургию 3-е изд., перераб. и доп. М.: Практическая медицина, 2018. $696 \mathrm{c.}$

6. Союз реабилитологов России. Порядок организации медицинской реабилитации [Электронный ресурc]. URL: https:// rehabrus.ru/materialyi/poryadok-organizaczii-mediczinskoj-reabilitaczii-1705.html (дата обращения: 06.04.2019).

7. Зубрицкая Е.М., Можейко Е.Ю., Прокопенко С.В., Гуревич В.А., Щетникова А.С. Коррекция когнитивных нарушений с использованием тренирующего воздействия на речевые домены мозга // Сибирское медицинское обозрение. 2018. № 2(110). C. 77-84. doi: 10.20333/2500136-2018-2-77-84

8. Демидюк В.Д. Оптимизация процесса реабилитации больных с использованием информационной системы «НейроДом»: магистерская диссертация. СибГУ им. М.Ф. Решетнева, 2019. С. 43-46.

9. Fkn+antitotal студентам \& программистам. Symfony порусски - Онлайн Справочник с примерами на русском языке. [Электронный ресурс]. URL: http://fkn.ktu10. com/?q=node/8071 (дата обращения: 10.02.2019).

10. Shenoy A., Sossou U. Learning Bootstrap. Packt Publishing, 2014. 204 p.

11. Cochran D. Twitter Bootstrap Web Development How-To. Packt Publishing, 2012. 68 p.

12. Spurlock J. Bootstrap: Responsive Web Development. O'Reilly, 2013. 128 p.

13. jQuery. [Электронный pecypc]. URL: https://jquery.com/ (дата обращения: 10.02.2019).

14. Chaffer J., Swedberg K. jQuery Reference Guide. Packt Publishing, 2007. 249 p.

15. WebReference.ru. Уроки по HTML и CSS. [Электронный pecypc]. URL: https://webref.ru/layout/learn-html-css (дата обращения: 10.02.2019).

16. Htmlbook. Tutorial CSS. [Электронный pecypc]. URL: http:// htmlbook.ru/samcss (дата обращения: 10.02.2019).

\section{Authors}

Tatiana N. Ivanilova - PhD, Associate Professor, Professor, Reshetnev Siberian State University of Science and Technology (SibSU named after M.F. Reshetnev), Krasnoyarsk, 660037, Russian Federation, ORCID ID: 0000-0002-1202-6609, ivanilova.tn@gmail.com

Irina V. Vasilenko - postgraduate, Reshetnev Siberian State University of Science and Technology (SibSU named after M.F. Reshetnev), Krasnoyarsk, 660037, Russian Federation, ORCID ID: 0000-0003-2555-5590, Vasilenko_irina@myrambler.ru

Victor A. Semenov - postgraduate, Reshetnev Siberian State University of Science and Technology (SibSU named after M.F. Reshetnev), Krasnoyarsk, 660037, Russian Federation, ORCID ID: 0000-0003-1343-5014, V1992@mail.ru

Igor A. Buslov - Assistant, Reshetnev Siberian State University of Science and Technology (SibSU named after M.F. Reshetnev), Krasnoyarsk, 660037, Russian Federation, ORCID ID: 0000-0001-5527-3370, vt244@mail.ru

Alexandra A. Ilminskaya - Resident of Department of Nervous Diseases, Krasnoyarsk State Medical University named after Prof. V.F.Voino-Yasenetsky, Krasnoyarsk, 660022, Russian Federation, ORCID ID: 0000-0001-9458-1608, sasha021@mail.ru

Svetlana A. Subocheva - Assistant of Department of Nervous Diseases, Krasnoyarsk State Medical University named after Prof. V.F.Voino-Yasenetsky, Krasnoyarsk, 660022, Russian Federation, ORCID ID: 0000-0001-9916-6235, Sveta162007@mail.ru
(Krasnoyarsk, 7-8 February. 2018). Krasnoyarsk, KrasSMU, 2018, pp. 326-332. (in Russian)

4. Popov A.A., Buslov I.A., Frishkina V.D. Database design portal of neurorehabilitation. Modern trends in the development of pedagogical technologies in medical education: Proc. AllRussian Conf. with International Participation (Krasnoyarsk, 7-8 February. 2018). Krasnoyarsk, KrasSMU, 2018, pp. 357-361. (in Russian)

5. Belova A.N. Scales, tests and questionnaries in neurology and neurosurgery. $3^{\text {rd }}$ ed. Moskow, Practical medicine Publ., 2018, 696 p. (in Russian)

6. Union of rehabilitation of Russia. The order of organization of medical rehabilitation. Available at: https://rehabrus.ru/materialyi/poryadok-organizaczii-mediczinskoj-reabilitaczii-1705.html (accessed: 06.04.2019). (in Russian)

7. Zubrickaya E.M., Mozhejko E.YU., Prokopenko S.V., Gurevich V.A., Shchetnikova A.S. Correction of cognitive disturbances by using the experimental impact on the speech brain domains. Siberian medical review, 2018, no. 2, pp. 77-84. (in Russian). doi: 10.20333/2500136-2018-2-77-84

8. Demidyuk V.D. Optimization of the process of rehabilitation of patients using the system "NeuroDom" [Text]: Dipl. work (dissertation of the master of computer science and computer technology), SibGU them. M.F. Reshetnev. Krasnoyarsk, 2018, pp. 43-46. (in Russian)

9. Fkn+antitotal students \& programmers. Symfony 3 - Online Guide with examples in Russian. Available at: http://fkn.ktu10. com/?q=node/8071 (accessed: 10.02.2019). (in Russian)

10. Shenoy A, Sossou U. Learning Bootstrap. Packt Publishing, 2014, 204 p.

11. Cochran D. Twitter Bootstrap Web Development How-To. Packt Publishing, 2012, 68 p.

12. Spurlock J. Bootstrap: Responsive Web Development. O'Reilly, 2013, $128 \mathrm{p}$.

13. jQuery. Available at: https://jquery.com/ (accessed: 10.02.2019).

14. Chaffer J., Swedberg K. jQuery Reference Guide. Packt Publishing, 2007, 249 p.

15. WebReference.ru. Lesson on HTML and CSS. Available at: https://webref.ru/layout/learn-html-css (accessed: 10.02.2019).

16. Htmlbook. Tutorial CSS. Available at: http://htmlbook.ru/samcss (accessed: 10.02.2019)

\section{Авторы}

Иванилова Татьяна Николаевна - кандидат технических наук, доцент, профессор, Сибирский государственный университет науки и технологий имени академика М.Ф. Решетнева, Красноярск, 660037, Российская Федерация, ORCID ID: 0000-0002-1202-6609, ivanilova.tn@gmail.com

Василенко Ирина Витальевна - аспирант, Сибирский государственный университет науки и технологий имени академика М.Ф. Решетнева, Красноярск, 660037, Российская Федерация, ORCID ID: 0000-0003-2555-5590, Vasilenko irina@myrambler.ru Семенов Виктор Александрович - аспирант, Сибирский государственный университет науки и технологий имени академика М.Ф. Решетнева, Красноярск, 660037, Российская Федерация, ORCID ID: 0000-0003-1343-5014,V1992@mail.ru

Буслов Игорь Александрович - ассистент, Сибирский государственный университет науки и технологий имени академика М.Ф. Решетнева, Красноярск, 660037, Российская Федерация, ORCID ID: 0000-0001-5527-3370,vt244@mail.ru

Ильминская Александра Андреевна - ординатор кафедры нервных болезней, Красноярский государственный медицинский университет имени профессора В.Ф. Войно-Ясенецкого, Красноярск, 660022, Российская Федерация, ORCID ID: 00000001-9458-1608, sasha021@mail.ru

Субочева Светлана Алексеевна - ассистент кафедры нервных болезней, Красноярский государственный медицинский университет имени профессора В.Ф. Войно-Ясенецкого, Красноярск, 660022, Российская Федерация, ORCID ID: 0000-0001-9916-6235, Sveta162007@mail.ru 